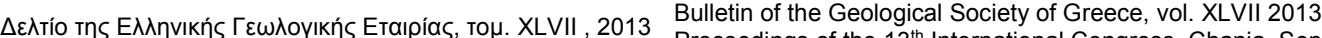

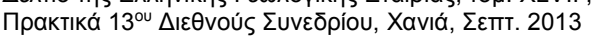

\title{
SPATIAL AND TEMPORAL DISTRIBUTION OF RAINFALL AND TEMPERATURE IN MACEDONIA, GREECE, OVER A THIRTY YEAR PERIOD, USING GIS
}

\author{
Grimpylakos G. ${ }^{1}$, Karacostas T. S. ${ }^{2}$ and Albanakis K. ${ }^{1}$ \\ ${ }^{1}$ Aristotle University of Thessaloniki, Faculty of Geology, Department of Physical and \\ EnvironmentalGeography,grimpyl@geo.auth.gr,albanaki@geo.auth.gr \\ ${ }^{2}$ Aristotle University of Thessaloniki, Faculty of Geology, Department of Meteorology and \\ Climatology,karac@geo.auth.gr
}

\begin{abstract}
Due to increased demand and use of water resources, the European Union has established the (WFD) Water Framework Directive 2000/60 for Community action in the field of water policy. In order to achieve better water protection and management, Member States must identify and analyse European waters, on the basis of individual river basin and district.

Precipitation and air temperature are directly related and at the same way interacted to the hydrological cycle and therefore with water resources. The objective on this study is to present the spatial and temporal distribution of precipitation and air temperature in Macedonia, by using GIS software (ArcMap 9.3).

The data used were retrieved from 82 different meteorological stations, which belong to the Ministry of Rural Development and Food, and correspond to the thirty year period (1974-2004); all stations provided continuous daily data of precipitation while 43 of them provided also daily data of temperature. The annual temperature range and the annual total precipitation amount were calculated, at each individual station, for the thirty years of the examined period. By using GIS software and triangular interpolation scheme, the thematic maps of Macedonia for the aforementioned parameters and thermal continentality $K$ were created. Furthermore, possible mean annual evapotranspiration for each meteorological station was estimated by Turc, Coutagne and Thornthwaite algorithms.

Key words: Interpolation, Annual temperature range, Thermal continentality, Evap-
\end{abstract} otranspiration, Water Framework Directive.

\section{Пєрі́ $\lambda \psi \eta$}

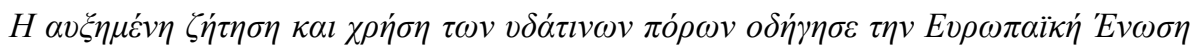

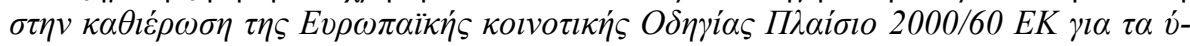

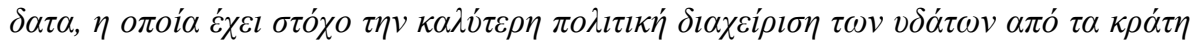

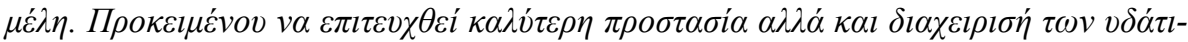

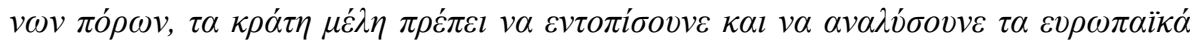

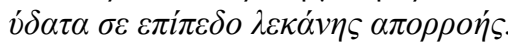

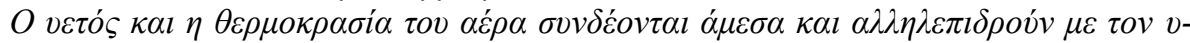

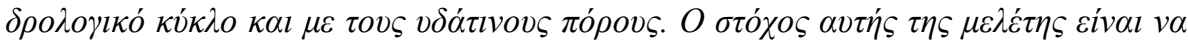

$\underline{\text { XLVII, No } 3-1458}$ 


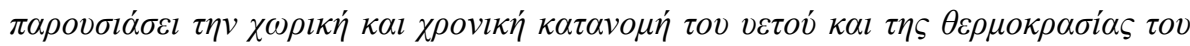

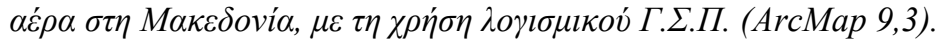

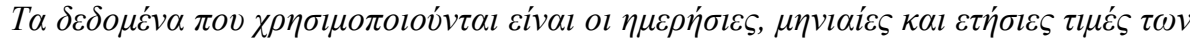

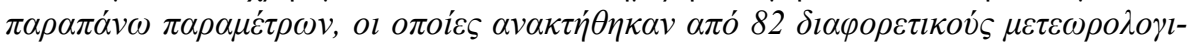

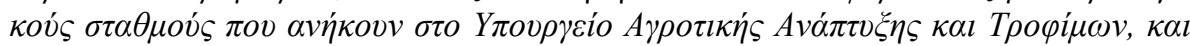

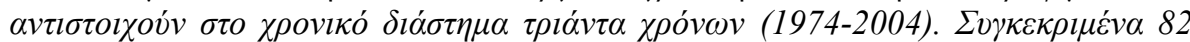

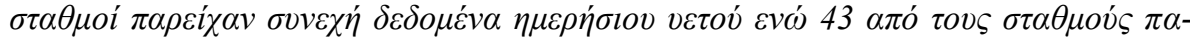

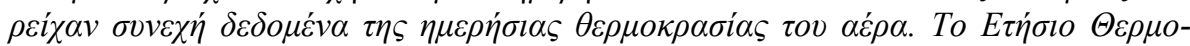

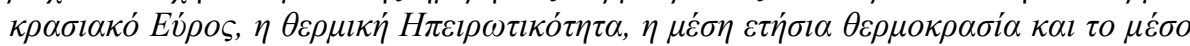

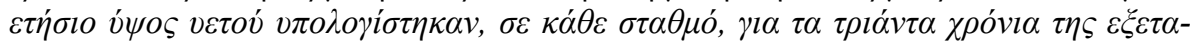

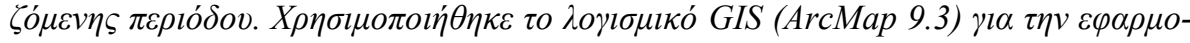

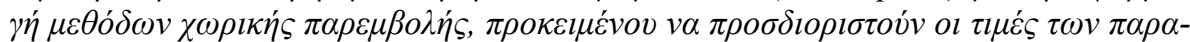

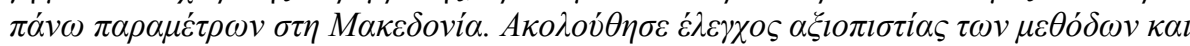

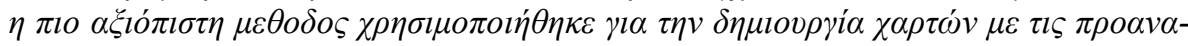

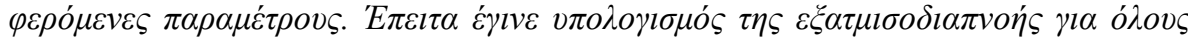

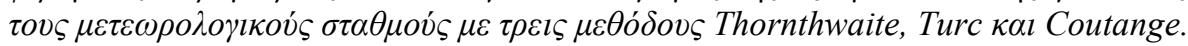

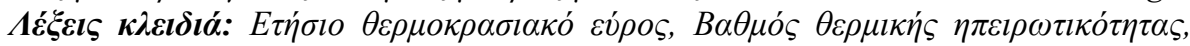

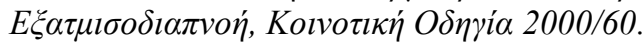

\section{Introduction}

Precipitation, air temperature and evapotranspiration are directly related and interacted with the water cycle. This article is part of a research, which examines the spatial and temporal distribution of the aforementioned climatic parameters in Macedonia Greece, in order to decide if these parameters should be used as one of the alternative factors of System B for Greece's river typology according to the (WFD) Water Framework Directive 2000/60 for Community action in the field of water policy. According to the WFD, Member States are obliged to classify all surface waters by one of the two typology systems, A or B. System A has fixed types with specific categorisation. System B can include alternative factors alongside with the obligatory factors of System A, but leaves to the analyst's discretion the categorisation of these factors as long as the new typology achieves at least the same level of categorisation as System A. (Kanli, 2009).

\section{Parameters, Data and Method}

\subsection{Climatic Parameters}

\subsubsection{Annual Temperature Range}

The annual course of temperature depends on the deviation of sun (position of sun according to earth in general), place's latitude and the respective path of solar radiation. At North hemisphere, higher temperature is observed during July or August while minimum during January or February (Zampakas, 1981). Mean annual Temperature at each station, derives by calculating the mean monthly temperature for a 30-year period and abstracting from the maximum monthly temperature the minimum monthly temperature as shown at table 2 . Annual temperature range can be used to categorise the climate type in 4 different types (Supan, 1880): i) $\mathrm{A} \leq 15^{\circ} \mathrm{C}$ Equator climate type, ii) $15^{\circ} \mathrm{C}<\mathrm{A} \leq 20^{\circ} \mathrm{C}$ Transitional maritime climate type and iii) $20^{\circ} \mathrm{C}<\mathrm{A} \leq 40^{\circ} \mathrm{C}$ Continental climate type, iv) $40^{\circ} \mathrm{C}<\mathrm{A}$ Extreme continental climate type.

\subsubsection{Parameter $\mathrm{K}$ of Thermal Continentality}

The index of thermal continentality, parameter $\mathrm{K}$, which is most often used in Europe was proposed by Gorczynski in 1918, (Mikolaskova, 2009).

$\underline{\text { XLVII, No } 3-1459}$ 


\section{Equation 1 - Gorczynski for Thermal Continentality}

$\mathrm{K}=1,7(\mathrm{~A}-12 \sin \theta) / \sin \theta$ or $\mathrm{K}=1,7 \mathrm{~A} / \sin \theta-20.4$

Parameter $\mathrm{K}$ is the index of continentality expressed as a percent, $\mathrm{A}$ is annual range of temperature in ${ }^{\circ} \mathrm{C}$ and $\theta$ is latitude in degrees (WGS84). Expression $\mathrm{A}=12 \sin \theta$ corresponds well to observations above sea (Gorczynski, 1922), constant 1.7 is calculated from the assumption that Verchojansk, in eastern Siberia, is representative of $100 \%$ continentality. $\mathrm{K}$ value range is $0-100$, where 0 is observed at sea locations, where climate is no longer influenced by continental surface and 100 at purely continental areas, where there is no influence from maritime air masses. This parameter is not applicable at low latitudes (Conrad and Pollak, 1950) but it is applicable in Greece. Gorczynski suggests three degrees of continentality according to parameter $K$ value: i) $0 \% \leq K \leq 33 \%$ Transitional maritime climate type, ii) $33 \%<\mathrm{K} \leq 66 \%$ Continental climate type and iii) $66 \%<\mathrm{K}$ $\leq 100 \%$ Extreme continental climate type.

\subsubsection{Evapotranspiration}

Although several variations of the definition exist, potential evapotranspiration (PET) can be generally defined as the amount of water that could evaporate and transpire from a vegetated landscape without restrictions other than the atmospheric demand (Thornthwaite, 1948; Penman, 1948; Jensen et al., 1990). Evapotranspiration (ET) is the sum of evaporation and plant transpiration from the Earth's land surface to atmosphere. To estimate ET, three methods were used in this study: Turc, Coutagne and Thornthwaite. These methods need the mean monthly and annual precipitation and the mean monthly and annual temperature.

- Turc algorithm, equation 2, for estimating ET, uses P mean annual precipitation in $\mathrm{mm}$ and $\mathrm{T}$ which is the mean annual temperature in ${ }^{\circ} \mathrm{C}$.

\section{Equation 2 - Turc algorithm for Evapotranspiration}

$\mathrm{E}=\mathrm{P} / \sqrt{ }\left(0,9+\mathrm{P}^{2} / \mathrm{L}^{2}\right)$, with $\mathrm{L}=300+25 \mathrm{~T}+0,05 \mathrm{~T}^{3}$

- Coutagne algorithm, equation 3, for estimating ET is applicable when the condition $1 / 8 \lambda \leq \mathrm{P}$ $\leq 1 / \lambda$ is valid, $\mathrm{P}$ is the mean annual precipitation in meters and $\mathrm{T}$ is mean annual temperature in ${ }^{\circ} \mathrm{C}$.

\section{Equation 3 - Coutagne algorithm for Evapotranspiration}

$\mathrm{E}=\mathrm{P}-\lambda \mathrm{P}^{2}$, with $\lambda=1 /(0,8+0,14 \mathrm{~T})$

- Thornthwaite algorithm requires latitude, daylight coefficient, soil moisture, mean monthly precipitation in mm and mean monthly temperature in ${ }^{\circ} \mathrm{C}$ (Palmer \& Havens, 1958; Pereira \& Camargo, 1989; Kerkikdes et.al., 1996; Mardikis et al., 2005; Dalezios \& Bartzokas, 2009).

\section{Equation 4 - Thornthwaite algorithm for Evapotranspiration}

$\operatorname{PET}_{\mathrm{i}}(\mathrm{L})=\mathrm{K}^{*} \operatorname{PET}_{\mathrm{i}}(0), \quad \operatorname{PET}_{\mathrm{i}}(0)=1,6^{*}\left(10 \mathrm{~T}_{\mathrm{i}} / \mathrm{J}\right)^{\mathrm{c}}, \quad \mathrm{J}=\Sigma_{\mathrm{i}=1}^{12}\left(\mathrm{I}_{\mathrm{i}}\right) \quad$ and $\mathrm{I}_{\mathrm{i}}=\left(\mathrm{T}_{\mathrm{i}} / 5\right)^{1,514}$

$\mathrm{T}_{\mathrm{i}}=$ mean $\mathrm{i}$ monthly temperature and $\mathrm{C}=0,000000675 * \mathrm{~J}^{3}-0,0000771 * \mathrm{~J}^{2}+0,01792 * \mathrm{~J}+0,49239$

$\operatorname{PET}_{\mathrm{i}}(0)=$ Potential Evapotranspiration at 0 latitude. Constant $\mathrm{K}$ differs according to latitude. For our case study at all meteorological stations the same constant $\mathrm{K}$ values were used and these are shown at table 1 .

Table 1 - Constant K values in Thornthwaite Method.

\begin{tabular}{|l|l|l|l|l|l|l|l|l|l|l|l|l|}
\hline Month & Jan & Feb & Mar & Apr & May & June & July & Aug & Sep & Oct & Nov & Dec \\
\hline K & 0,83 & 0,83 & 1,3 & 1,11 & 1,25 & 1,26 & 1,27 & 1,19 & 1,04 & 0,96 & 0,82 & 0,8 \\
\hline
\end{tabular}


Average monthly precipitation is estimated by averaging the overall precipitation for each month for 1974-2004. Mean annual precipitation is very reliable measured at points where meteorological stations are situated and was estimated by summing the average monthly precipitation for the same period. Average monthly temperature is estimated by averaging the average temperature for each month during the period of 1974-2004. Mean annual temperature was estimated by averaging the monthly average temperature for the aforementioned period.

\subsection{Studying Area and Data}

Macedonia is a district of North Greece as shown at figure 1. Studying area is a polygon that includes all the watersheds of Macedonia's torrents and rivers, resulting in a polygon the boundaries of which differ from the boundaries of Macedonia's political district. The boundaries were determined BY THE Ministry of Rural Development and Food in collaboration with the Institute of Geology and Mineral Exploration and always according to the WFD guidelines for water bodies. Studying area is $36290 \mathrm{~km}^{2}$, has a perimeter of $2163 \mathrm{~km}$ and includes 77 different torrents in which main rivers are divided according to WFD and the watersheds are of $3-4775 \mathrm{~km}^{2}$.

Ministry of Rural Development and Food provided data from 82 meteorological stations, which correspond to different time periods during an eighty year period (1930-2010) and include daily, monthly and annual measurements of precipitation, while 43 of them included also daily monthly and annual measurements of temperature. In order to study the climatic parameters for a given area, a 30-year period with good spatial and temporal distribution is needed. For our studying area, after sorting the data from all 82 meteorological stations the best period corresponded to 19742004, as all data were daily and continuous for this period.

Table 2 - Annual Temperature Range A at each station with the minimum and maximum mean $T$ for period 1974-2004.

\begin{tabular}{|l|l|l|l|l|}
\hline \multicolumn{1}{|c|}{ Station } & \multicolumn{1}{|c|}{ County } & \multicolumn{1}{c|}{ M } & \multicolumn{1}{c|}{ Minimum T } & \multicolumn{1}{c|}{ Maximum T } \\
\hline Ano kalliniki & Florina & 21,3 & 2,0 Jan & 23,3 July \\
\hline Limnochori & Florina & 19,9 & 2,6 Jan & 22,5 July \\
\hline Amuntaio & Florina & 20,0 & 3,0 Jan & 23,0 July \\
\hline Tropaiouxos & Florina & 20,6 & 1,0 Jan & 21,6 july \\
\hline Monospita & Imathia & 20,6 & 4,2 Jan & 24,8 July \\
\hline Rodochori & Imathia & 19,9 & 3,7 Jan & 23,6 July \\
\hline Exaplatanos & Pella & 20,0 & 4,5 Jan & 24,5 July \\
\hline Vrontous & Pieria & 19,7 & 5,5 Jan & 24,5 July \\
\hline Moschopotamos & Pieria & 19,5 & 4,9 Jan & 24,3 July \\
\hline Saint Paraskevi & Grevena & 19,8 & 3,0 Jan & 22,7 July \\
\hline Alatopetra & Grevena & 19,2 & 2,2 Feb & 21,5 July \\
\hline Krua Vrusi & Pella & 20,5 & 4,0 Jan & 24,5 July \\
\hline Plana & Chalkidiki & 19,1 & 5,3 Jan & 24,5 Aug \\
\hline Ano Theodoraki & Kilkis & 19,2 & 4,0 Jan & 23,2 July \\
\hline Metaxochori & Kilkis & 19,4 & 3,4 Jan & 22,8 July \\
\hline Melanthio & Kilkis & 19,4 & 3,4 Jan & 22,8 July \\
\hline Nea Chalkidona & Thes $\backslash n i k i$ & 20,5 & 4,7 jan & 25,2 July \\
\hline Chalastra & Thes $\backslash n i k i$ & 20,2 & 4,7 jan & 24,9 July \\
\hline Drama & Drama & 21,0 & 4,1 Jan & 25,1 July \\
\hline Kato Nevrokopi & Drama & 20,8 & 0,2 jan & 21 July \\
\hline Kalampaki & Drama & 20,5 & 4,2 Jan & 24,7 July \\
\hline Argyroupoli & Drama & 21,6 & 3,7 Jan & 24,3 Aug \\
\hline Leukogia & Drama & 21,7 & 0,6 Jan & 22,1 July \\
\hline Prinos Thasou & Kavala & 20,0 & 4,9 Jan & 24,9 July \\
\hline
\end{tabular}

XLVII, No 3 - 1461 
Data from 43 meteorological stations, of the studying area, were available to be used in order to calculate the mean monthly and annual temperature, the annual temperature range $\mathrm{A}$ and the parameter K of thermal continentality. The data were of different periods during 1950-2010 and of different time continuity, 12-65 years. Period 1974-2004 was chosen to be used because most stations had data for this period. After sorting the data from the meteorological stations, 32 of them had data during the aforementioned period but only 24 had continuously data for the whole period of 30 years; therefore these stations were used (Table 2).

For the mean annual precipitation analysis, over the 82 meteorological stations only 64 had continuous data for the period 1974-2004 (Table 3) and included the 24 stations that were used to calculate the annual temperature range A. As there was a big diversity in the spatial distribution of the 24 and 64 meteorological stations, it was decided that two thematic maps should be constructed, with the spatial and temporal distribution of the precipitation through Macedonia. Afterwards, these thematic maps were checked for similarities and differences (Figure 6 and 7).

Table 3 -Mean Precipitation at each station for period 1974-2004 and the geographical position in EGSA 87 (meters).

\begin{tabular}{|c|c|c|c|c|c|}
\hline Station & County & $\mathbf{P}(\mathrm{mm})$ & Altitude & Longitude & Latitude \\
\hline Ano kalliniki & Florina & 521,1 & 634,6 & 284948,045 & 4526799,972 \\
\hline Limnochori & Florina & 541,3 & 598,9 & 294062,520 & 4500615,249 \\
\hline Amuntaio & Florina & 438,1 & 579,0 & 304125,020 & 4507749,929 \\
\hline Polypotamos & Florina & 619,0 & 1000,0 & 276016,096 & 4510396,803 \\
\hline Skopos & Florina & 435,7 & 775,0 & 300399,873 & 4526365,940 \\
\hline Tropaiouxos & Florina & 622,7 & 695,0 & 283109,746 & 4512037,983 \\
\hline Veui & Florina & 535,1 & 734,7 & 297286,337 & 4515340,333 \\
\hline Aalexandria & Imathia & 690,2 & 750,0 & 367360,434 & 4498948,430 \\
\hline Monospita & Imathia & 596,9 & 47,0 & 346179,189 & 4497504,857 \\
\hline Koumaria & Imathia & 1020,6 & 700,0 & 344499,751 & 4484582,860 \\
\hline Rodochori & Imathia & 801,2 & 545,0 & 332288,798 & 4507060,477 \\
\hline Ergochori & Imathia & 643,2 & 107,0 & 347437,793 & 4490075,164 \\
\hline Trilofos & Imathia & 697,2 & 151,5 & 344653,693 & 4491983,540 \\
\hline Exaplatanos & Pella & 635,6 & 133,0 & 342816,284 & 4538298,946 \\
\hline Notia & Pella & 446,2 & 590,0 & 348692,164 & 4551133,402 \\
\hline Theodoraki & Pella & 876,7 & 424,0 & 348348,671 & 4534480,631 \\
\hline Promachonas & Pella & 890,2 & 250,0 & 329206,902 & 4433086,364 \\
\hline Skydra & Pella & 550,7 & 46,0 & 343710,041 & 4514215,579 \\
\hline Ktima Kastorias & Kastoria & 596,0 & 690,0 & 268286,411 & 4488408,209 \\
\hline Vrontous & Pieria & 850,2 & 180,0 & 352321,397 & 4451109,708 \\
\hline Kolindros & Pieria & 664,2 & 300,0 & 372715,011 & 4482198,998 \\
\hline Lofos & Pieria & 821,8 & 250,0 & 362285,404 & 4452772,325 \\
\hline Mosxopotamos & Pieria & 775,1 & 516,0 & 356858,373 & 4465828,328 \\
\hline Trilofos & Pieria & 695,9 & 318,0 & 369664,889 & 4469296,912 \\
\hline Deskati & Grevena & 668,0 & 850,0 & 311867,150 & 4422388,357 \\
\hline Saint Paraskevi & Grevena & 727,1 & 615,0 & 281013,000 & 4439877,045 \\
\hline Alatopetra & Grevena & 857,0 & 1250,0 & 262479,391 & 4438582,591 \\
\hline Anabruta & Grevena & 920,2 & 860,0 & 282381,140 & 4437985,969 \\
\hline Kariotissa & Pella & 533,1 & 9,0 & 356483,832 & 4514111,447 \\
\hline Krua Vrusi & Pella & 524,2 & 8,0 & 356302,515 & 4504740,156 \\
\hline Trikala & Imathia & 572,1 & 7,0 & 363097,862 & 4497174,779 \\
\hline Megali Panagia & Chalkidiki & 679,8 & 440,0 & 471584,641 & 4477471,821 \\
\hline Plana & Chalkidiki & 550,8 & 11,5 & 471556,731 & 4470071,868 \\
\hline
\end{tabular}




\begin{tabular}{|l|l|l|l|l|l|} 
Ormulia & Chalkidiki & 472,8 & 40,0 & 461606,877 & 4460865,882 \\
\hline Rizes & Chalkidiki & 742,0 & 350,0 & 451902,804 & 4483187,002 \\
\hline Ano Theodoraki & Kilkis & 495,2 & 480,0 & 415959,912 & 4557455,098 \\
\hline Metaxoxori & Kilkis & 565,1 & 63,0 & 411631,530 & 4546402,983 \\
\hline Melanthio & Kilkis & 618,8 & 490,0 & 419912,640 & 4535205,366 \\
\hline Nea Chalkidona & Thessaloniki & 508,6 & 29,5 & 381632,419 & 4509811,675 \\
\hline Chalastra & Thessaloniki & 443,1 & 4,0 & 393266,166 & 4535543,332 \\
\hline Kalamoto & Thessaloniki & 787,0 & 220,0 & 446284,268 & 4488778,629 \\
\hline Mavrouda & Thessaloniki & 687,0 & 360,0 & 453583,750 & 4516454,322 \\
\hline Diavata & Thessaloniki & 461,3 & 14,0 & 402694,802 & 4505804,818 \\
\hline Vraxia & Thessaloniki & 415,6 & 2,0 & 384332,087 & 4502366,704 \\
\hline Drama & Drama & 645,5 & 101,0 & 511038,602 & 4555131,545 \\
\hline Kato Nevrokopi & Drama & 725,7 & 580,0 & 488696,344 & 4577334,585 \\
\hline Nikiforos & Drama & 642,1 & 236,0 & 525017,441 & 4557016,570 \\
\hline Livadero & Drama & 877,5 & 650,0 & 517855,148 & 4625457,932 \\
\hline Mikropoli & Drama & 934,4 & 360,0 & 484478,409 & 4560689,863 \\
\hline Kalampaki & Drama & 645,2 & 67,3 & 515257,514 & 4544037,941 \\
\hline Argyroupoli & Drama & 746,5 & 74,0 & 502648,896 & 4551423,084 \\
\hline Leukogia & Drama & 856,5 & 621,4 & 490098,077 & 4582883,456 \\
\hline Exochi & Drama & 715,0 & 620,0 & 484529,212 & 4584743,409 \\
\hline Katafygio & Drama & 745,1 & 761,0 & 473359,448 & 4577374,373 \\
\hline Ochyro & Drama & 1127,5 & 543,0 & 487292,487 & 4571786,029 \\
\hline Iraklia & Serres & 515,9 & 35,0 & 439744,333 & 4559070,950 \\
\hline Provatas & Serres & 467,5 & 18,0 & 449439,899 & 4546045,337 \\
\hline Lower Kamila & Serres & 554,4 & 10,0 & 456419,478 & 4542300,120 \\
\hline Worksite Serres & Serres & 523,1 & 56,0 & 460652,182 & 4547827,040 \\
\hline Eleftheroupoli & Kavala & 719,7 & 80,0 & 520902,445 & 4529250,503 \\
\hline Gialochoria & Kavala & 485,6 & 7,0 & 498443,104 & 4508869,290 \\
\hline Prinos Thasou & Kavala & 716,7 & 684,0 & 548325,837 & 4510168,565 \\
\hline Chrysoupoli & Kavala & 569,8 & 18,0 & 558736,979 & 4536856,957 \\
\hline Moustheni & Kavala & 701,0 & 151,0 & 509333,916 & 4522296,22 \\
\hline & & & & & \\
\hline & & & & \\
\hline
\end{tabular}

The data for calculating the potential evapotranspiration at each station derived from daily data of 24 stations at 1974-2004 period that were used for the estimation of annual temperature range, thermal continentality $\mathrm{K}$ and mean annual precipitation. These stations and data were chosen because Turc, Coutagne and Thornthwaite methods needed the mean monthly and annual temperature and precipitation in order to calculate PET. The high resolution Digital elevation model (DEM) with $28.3 \times 28.3$ cell size was used, which was constructed from the Advanced Spaceborne Thermal Emission and Reflection Radiometer (ASTER) of NASA Terra satellite.

\subsection{Method}

\subsubsection{Spatial Interpolation}

A very basic problem in spatial analysis is interpolating a spatially continuous variable from point samples. Spatial interpolation techniques predict values for cells in raster from a limited number of sample point data. According to first law of Geography, "Everything is related to everything else, but near things are more related than distant things" (Tobler, 1970). Unknown values are predicted with a mathematical formula that uses the values measured at nearby points. There are many different spatial interpolation techniques. Some of the most commonly used interpolation methods to model spatially distribution from point data are the following three: Inverse Distance Weighting 
(IDW), spline and ordinary kriging. Overall, anomalies of local scale can be adjusted without affecting the values derived from interpolation at other points on the surface (Burrough and McDonnell, 1998).

\subsubsection{Inverse Distance Weighted IDW}

Inverse distance weighted (IDW) is a method of interpolation that estimates cell values by averaging the values of nearby measured data points. The main logic rule behind this technique is that the cell values next to each other are most likely to have same values, so the value of the predicted cell is more influenced by the value of cells closer than those that are further away. This technique weights the points closer to the prediction location greater than those farther away, hence the name inverse distance weighted (Watson and Philip, 1985). However the main problem with this technique is that it assumes that maximum and minimum values are measured at the sampled points and all other unsampled points have values between those values.

\subsubsection{Spline Interpolation}

Spline is an interpolation method in which cell values are estimated using a mathematical function that minimizes overall surface curvature, resulting in a smooth surface that passes exactly through the input points. It is a deterministic, locally stochastic interpolation technique, which represents two-dimensional curves on three-dimensional surfaces (Eckstein, 1989; Hutchinson and Gessler, 1994).

\subsubsection{Kriging}

The aforementioned methods are known as deterministic interpolation methods because they are directly based on the surrounding measured values and use specified mathematical formulas that determine the smoothness of the resulting surface. On the other hand, kriging uses statistical models that include autocorrelation among measured points, in order to predict the values at unknown points. The most commonly applied form uses "semivariogram" among pairs of sampled points. Kriging interpolation method was developed by Matheron in 1970.

\subsubsection{Validation}

All data were divided in 2 groups. The first group was named "training" and content $90 \%$ of sample points while the second group was named "test" and content $10 \%$ of the sample points. Training group's measurements were used for predicting the values of the examined variable at whole Macedonia by using the aforementioned interpolation methods. Test's group was used to validate the results of each method.

\section{Results}

\subsection{Annual Temperature Range}

In order to predict the Annual Temperature Range at Macedonia district, 24 sample points were used and divided in two subsets; the test group had 3 sample points which were randomly chosen from the 24 with only rule to be positioned within the rest and not at the edges of the study area, while the rest 21 sample points were the training group. Each interpolation method was applied at the training group and the predictions were validated using the test group (Table 4).

Table 4 - Estimated values of Annual Temperature Range by each method.

\begin{tabular}{|l|r|r|r|r|r|}
\hline \multirow{2}{*}{ Meteorological Stations } & \multirow{2}{*}{$\begin{array}{c}\text { Measured } \\
\text { Values }\end{array}$} & \multicolumn{4}{|c|}{ Predicted Values } \\
\cline { 3 - 6 } & 19,9 & \multicolumn{1}{|c|}{ IDW } & \multicolumn{1}{c|}{ Krigging } & \multicolumn{1}{c|}{ Spline } & Polvnomial \\
\hline Limnochori & 20 & 20,19 & 20,11 & 19,9 & 20,31 \\
\hline Exaplatanos & 20,6 & 20,35 & 20,33 & 20,56 & 20,34 \\
\hline Monospita & & 0,091 & 0,133 & 0,159 & 0,134 \\
\hline Root Mean Square Error & & &
\end{tabular}

XLVII. No 3 - 1464 
The validation showed that the best method was Inverse Distance Weighting. Furthermore, a raster file with cell value of $750 \mathrm{~m}$ was created, by using IDW method and data from all 24 meteorological stations. Two thematic maps were constructed, the first visualised the spatial distribution of annual temperature range A at Macedonia (Figure 1) and the second one (Figure 2) showing the categorization of Macedonia in two climatic types, according to A values (Supan 1880). Finally possible correlation between $A$ and elevation was checked and $R^{2}=0,034$ meaning not significant correlation.

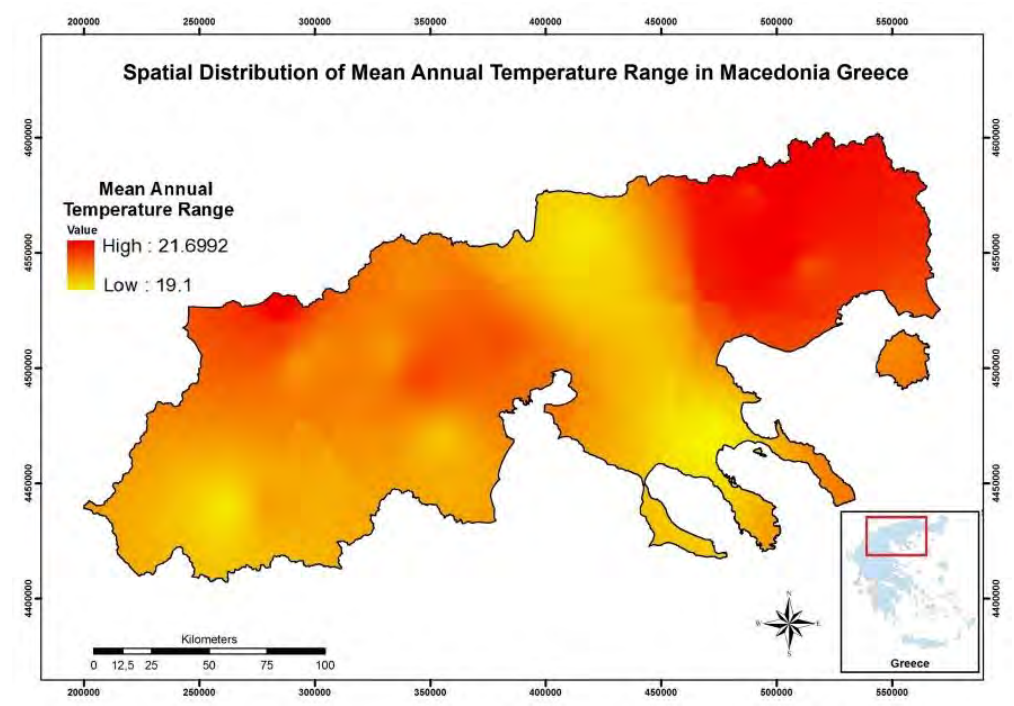

Figure 1 - Stretched map showing the gradual spatial distribution of A at Macedonia.

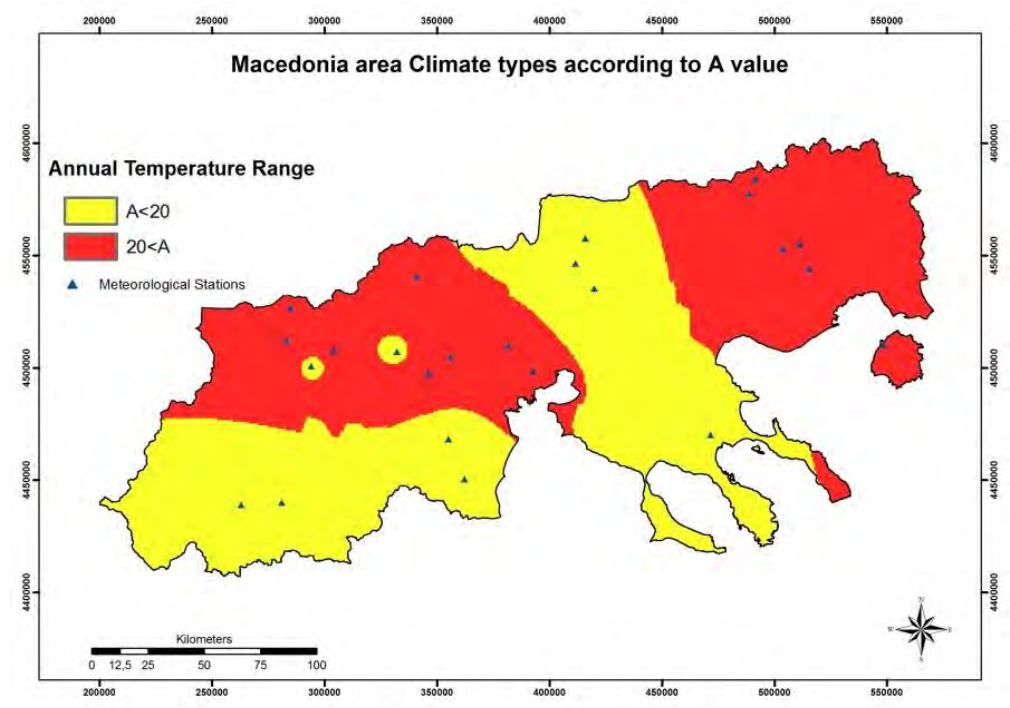

Figure 2 - Macedonia area climate types according to A value (Supan 1880).

\subsection{Thermal Continentality $K$}

Thermal continentality was constructed by applying the $\mathrm{K}$ algorithm at Raster calculator of ArcMap 9.3. In order to do this, two raster files of cell size 750 meters were used: one file with the annual temperature range value (the raster file thaw was previously constructed with IDW) and a second one with the latitude values per cell in WGS84. The results of the K were visualised with a 
stretched thematic map, where $\mathrm{K}$ values ranged 29,18 - 35,42. Macedonia was divided in two different climate types according to the categorization of Gorczynski (Figure 3). Finally possible correlation between $\mathrm{K}$ and elevation was checked and $\mathrm{R}^{2}=0,025$ meaning not significant correlation.

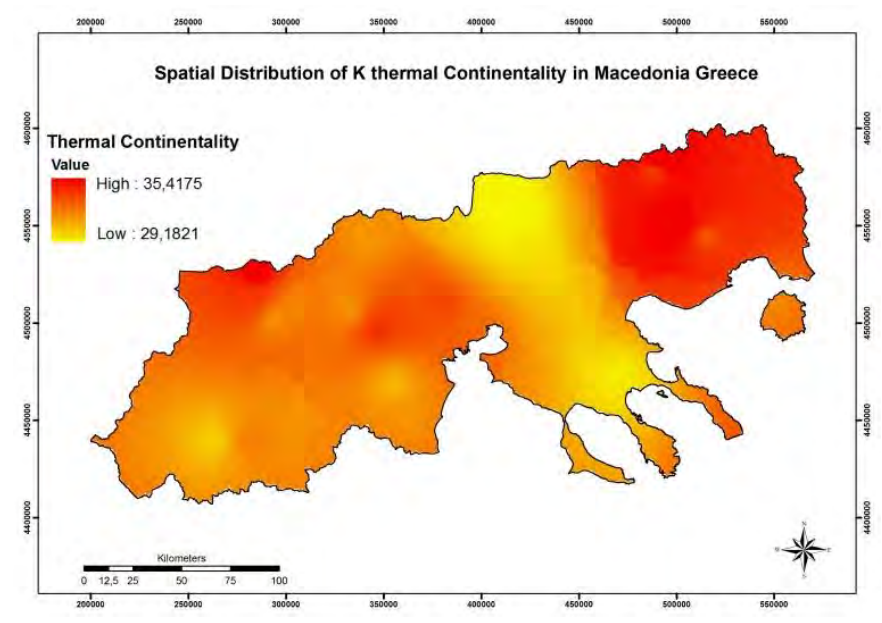

Figure 3 - Stretched map showing the gradual spatial distribution of $\mathrm{K}$ at Macedonia.

Mean annual temperature was estimated for each of the 24 meteorological stations that had continuous data for 1974-2004. Firstly, the mean monthly temperature for each meteorological station was calculated and then, the mean of these values gave the mean annual temperature. There is significant correlation between Mean annual Temperature and elevation where $\mathrm{R}^{2}=0,7234$ as shown at Figure 4 and the corresponding equation 4 shows that the temperature declines as the elevation rises.

\section{Equation 5 - Grimpylakos algorithm for Temperature at Macedonia}

$\mathrm{T}=-0,0038 * \mathrm{E}+14,904$ ( $\mathrm{T}$ is mean annual temperature and $\mathrm{E}$ is elevation).

The $\mathrm{R}$ square value $\left(\mathrm{R}^{2}\right)$, means that the mean annual temperature is $72,34 \%$ explained by elevation. Finally the equation was applied at raster calculator of ArcMap in order to estimate the temperature at the meteorological stations with no Temperature data.

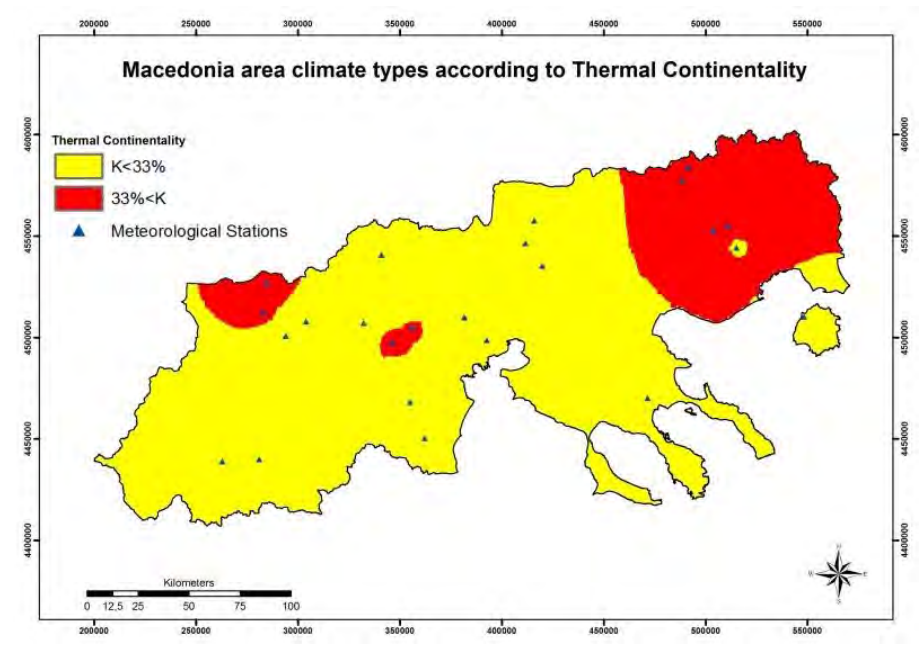

Figure 4 - Macedonia area climate types according to Thermal Continentality value.

$\underline{\text { XLVII, No } 3-1466}$ 


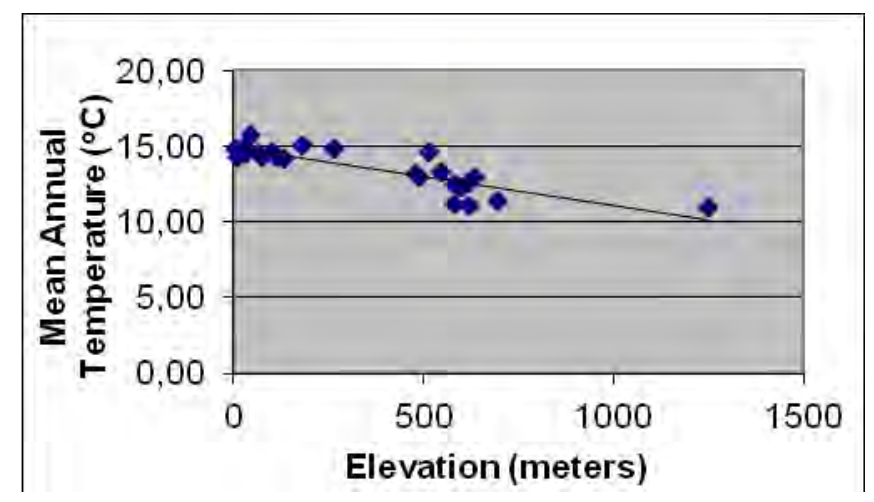

Figure 5 - Correlation of mean annual temperature with elevation.

\subsection{Mean Annual Precipitation}

Mean monthly precipitation was estimated for each month at all 24 and 64 meteorological stations and their total for mean annual precipitation was calculated. Two thematic maps were created showing the mean annual precipitation in Macedonia by using the interpolation method of Inverse distance weighted. The spatial distribution of the mean annual precipitation that derived from the data of 64 meteorological during 1974-2004 is projected at figure 6 . The spatial distribution of the mean annual precipitation that derived from the data of 24 meteorological during 1974-2004 is projected at figure 7.The correlation between elevation and precipitation was checked with SPSS programme (Table 5). The highest possible correlation was not significant $\mathrm{R}^{2}<0,21$ and so the mean annual precipitation for each cell of Macedonia could not be estimated and the corresponding thematic map using an equation between the elevation and the mean annual precipitation was not projected as it would have been inaccurate.

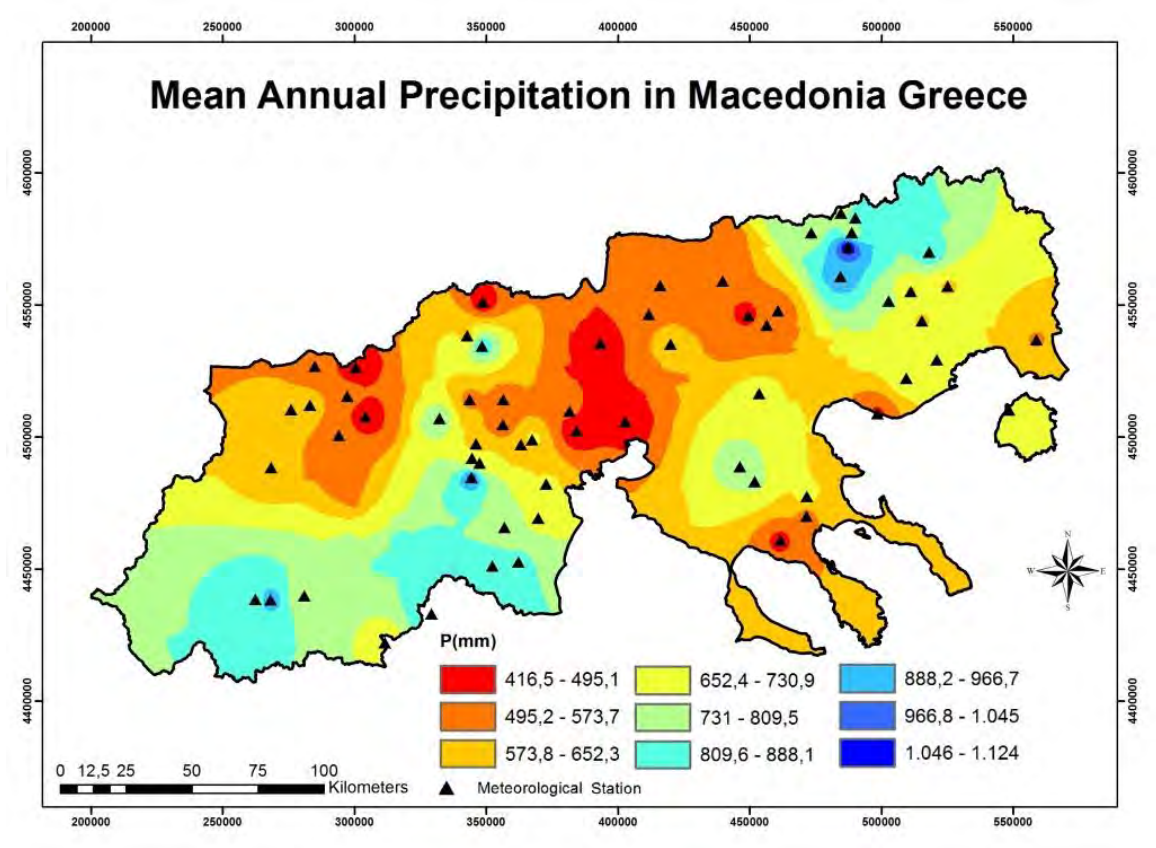

Figure 6 - Spatial distribution of mean annual precipitation at Macedonia Greece derived from 64 meteorological stations during period 1974-2004. 
Table 5 - Correlation of Variables with Elevation.

\begin{tabular}{|l|r|r|r|r|r|r|r|}
\hline \multirow{2}{*}{ Elevation } & \multicolumn{9}{|c|}{ Examined Variable } \\
\cline { 2 - 8 } & $\mathbf{T}\left({ }^{\circ} \mathbf{C}\right)$ & $\mathbf{P}(\mathbf{m m})$ & \multicolumn{1}{|c|}{ K } & \multicolumn{1}{|c|}{$\mathbf{A}$} & Thornthwaite & \multicolumn{1}{c|}{ Turc } & Coutagne \\
\hline Pearson & $-0,851$ & 0,306 & $-0,157$ & $-0,184$ & 0,156 & $-0,072$ & 0,108 \\
\hline R-square & 0,723 & 0,094 & 0,025 & 0,034 & 0,024 & 0,005 & 0,012 \\
\hline
\end{tabular}

The thematic map that derived from the 24 stations missed mean annual precipitation values between 416,5 - 438,3 and 856,9 - 1124 as these data did not exist at the 24 stations. The data distribution of the 24 stations at West, central and South Macedonia is very sparse resulting in much less zones of precipitation. The map of 64 stations has good spatial distribution and is more accurate and should be used for analysis purposes.

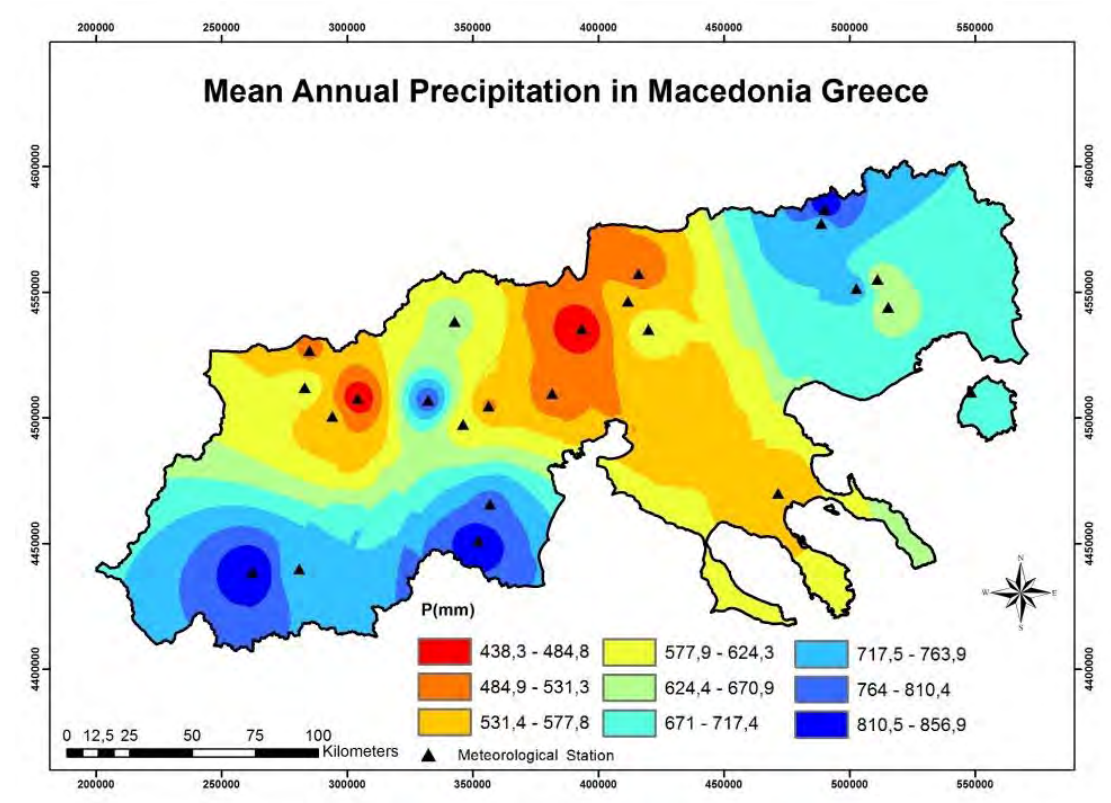

Figure 7 - Spatial distribution of mean annual precipitation at Macedonia Greece derived from 24 meteorological stations during period 1974-2004.

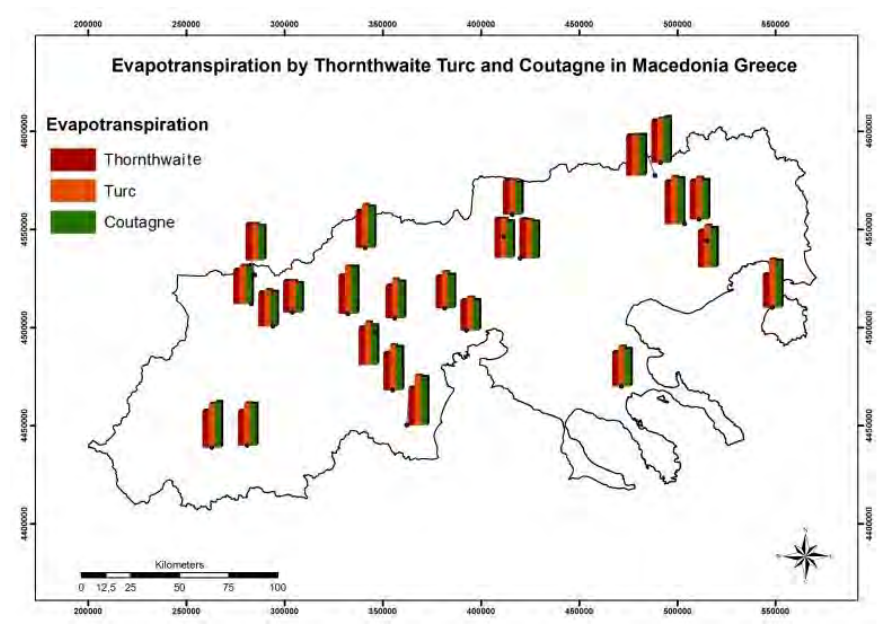

Figure 8 - Evapotranspiration in Macedonia Greece.

$\underline{\text { XLVII, No } 3-1468}$ 


\subsection{Evapotranspiration}

Evapotranspiration was calculated with all three methods for each of the 24 stations (Figure 6). Evapotranspiration by Turc method is higher than Thornthwaite method at all stations and in 21 of 24 stations it is higher than Coutagne method, while Coutagne is higher than Thornthwaite method at 19 of 24 stations. On the other hand, Turc method is the most easily applied method of all, as Coutagne method is not always applicable and Thornthwaite's method uses parameters that differ according to elevation and the spatial distribution of each examined place, which makes it very difficult to apply this method at all stations. No significant correlation between elevation and evapotranspiration (Table 5). Finally Thornthwaite method is underestimating the evapotranspiration in comparison with the other two methods.

\section{Discussion}

There were small differences between predicted and measured values among the four interpolation methods that were tested for predicting A, annual temperature range, as noted also by Sailesh et al., 2012; in our case, IDW was the most accurate one as shown at table 4 as it has the smallest residuals. The spatial distribution of temperature data in central and Northwest Macedonia is very good. The estimation of annual temperature range $\mathrm{A}$ and thermal continentality $\mathrm{K}$ north of 4450000 meters and west of 525000 meters (GCS GGRS 1987) was accurate. On the other hand, the estimation of the variables, South and East of the aforementioned coordinates, needs to be crosschecked with meteorological data of nearby areas as data's spatial distribution at these areas is weak. Annual temperature range value is increasing as the distance from sea is increasing and while moving to the North (Nastos et al., 1995) as shown at figure 1a; classification by Supan (1880) divided Macedonia in two zones (figure 1b). Thermal continentality classification by Gorczynski (1922) divided Macedonia in two similar zones to A of Supan (1880) (Figure 4). From the combination of the results of $\mathrm{A}$ and $\mathrm{K}$ spatial distribution a final map was constructed and Macedonia was divided into the following three zones (Figure 7):

- $0 \% \leq \mathrm{K} \leq 33 \%$ and $15^{\circ} \mathrm{C}<\mathrm{A} \leq 20^{\circ} \mathrm{C}$ Transitional Maritime climate type

- $0 \% \leq \mathrm{K} \leq 33 \%$ and $20^{\circ} \mathrm{C}<\mathrm{A} \leq 40^{\circ} \mathrm{C}$ Transitional Continental climate type

- $15^{\circ} \mathrm{C}<\mathrm{A} \leq 20^{\circ} \mathrm{C}$ and $33 \%<\mathrm{K} \leq 66 \%$ Transitional Continental climate type

- $33 \%<\mathrm{K} \leq 66 \%$ and $20^{\circ} \mathrm{C}<\mathrm{A} \leq 40^{\circ} \mathrm{C}$ Continental climate type.

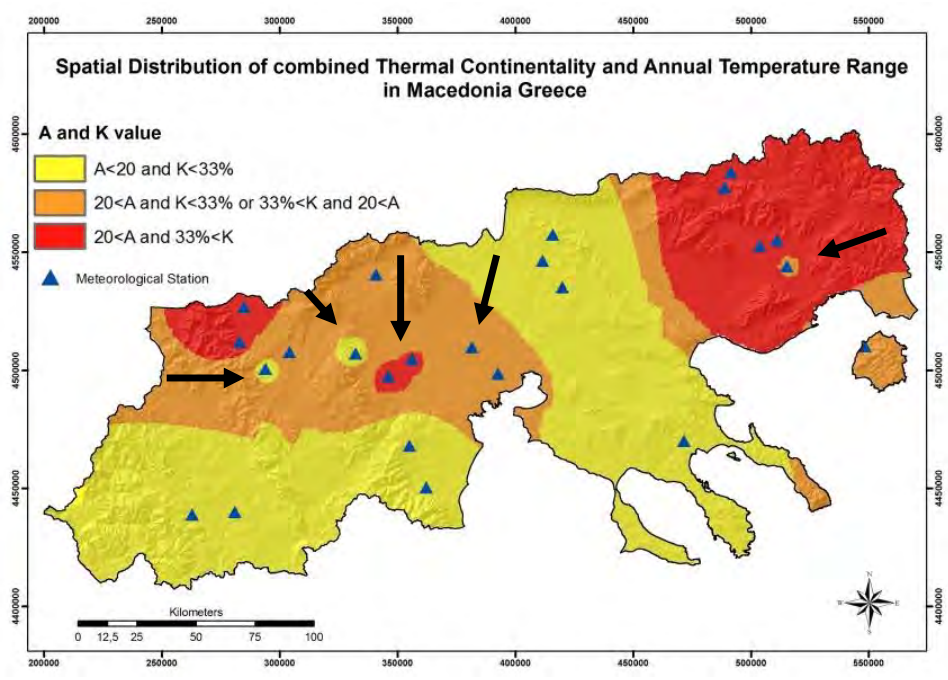

Figure 9 - Macedonia is divided in three climate types according to the author.

$\underline{\text { XLVII, No } 3-1469}$ 
During the interpretation of the results as shown at figure 9, five anomalies can be observed at the map; at the two red arrows that show three stations with high A and $\mathrm{K}$ values, because the IDW method was not able to connect those two areas as it should have done, meaning this red small circles are not anomalies but a red zone situated Northwest of Katerini - Thessaloniki. The two yellow anomalies have $A=19,9<20$ classification by Supan (1880), while the orange has $\mathrm{K}=32,95 \%<33 \%$, classification by Gorczynski (1922); both cases can be included in the surrounding zone. The red arrows anomaly can be avoided with supervised classification. The elevation distribution of the meteorological stations was not adequate to check the possible correlation between Precipitation and Elevation at Macedonia and to create an equation. A map showing the spatial distribution of Evapotranspiration could not be created, as Precipitation values were necessary, that could not be precisely estimated. Mean annual precipitation, evapotranspiration and total runoff at each meteorological station were estimated and projected (Figure 10) alongside with the anaglyph. Total runoff is very strong correlated with high elevation and low temperature. Total runoff is higher at Southwest part of Macedonia west of Pindos mountain chain. The strong correlation with elevation is explained by the fact that at high elevation precipitation is higher while mean monthly and annual temperature is lower. This correlation is a proof that elevation distribution of each torrent watershed should be included in the classification of rivers typology; however in the elevation classification the relationship with the total runoff should be taken in consideration.

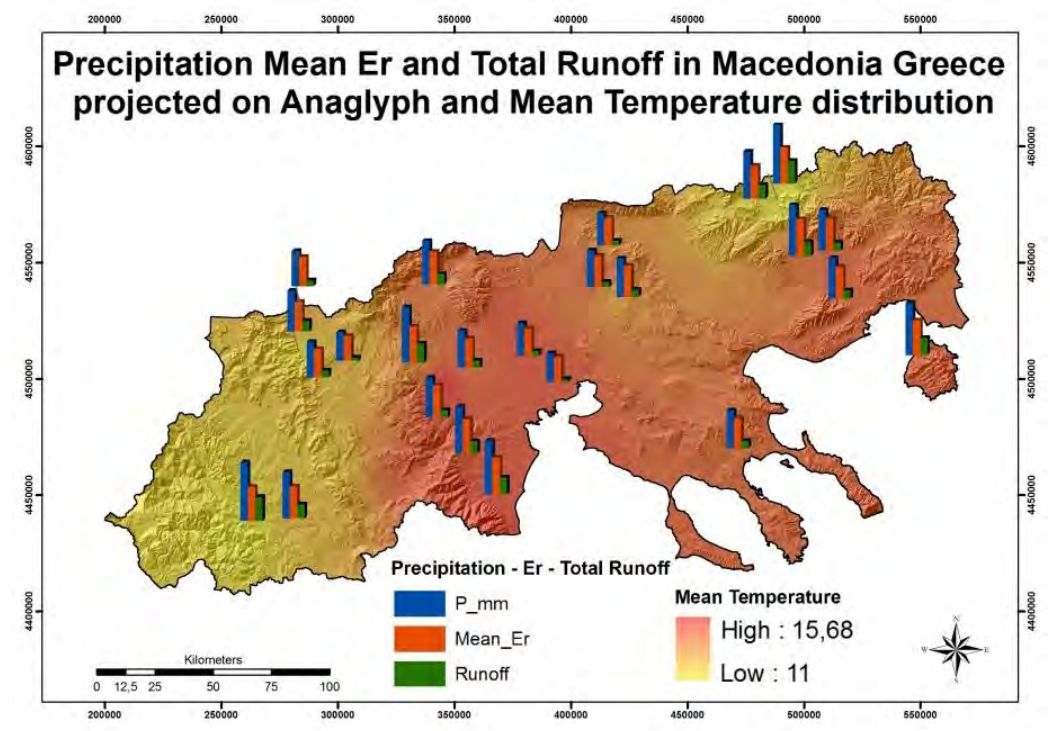

Figure 10 - Distribution of Precipitation Evapotranspiration and runoff in Macedonia Greece. On the background mean $T$ and anaglyph is projected.

\section{Acknowledgments}

To Papadakou Stavroula, Drosos Efthumios, Pilalitos Konstantinos, Tsarmpos Vasileios and Leoutsarakos Nickolaos of Department of Geology and Hydrology of Ministry of Rural Development and Food, for providing the meteorological data for Macedonia. Grimpylakou Lina, for software advice in GIS-ArcMap. Tamtelen Anastasia, for data interpretation.

\section{References}

Apostolaki E.K. 2009. Typology and river type specific reference conditions at the basin of tauropo lake, Interdepartmental Postgraduate Program "Ecological Water Quality and Management at a River Basin level", Master Thesis, A.U.TH.

XLVII. No $3-1470$ 
Burrough P.A and McDonnell R.A. 1998. Principles of geographical information systems, Oxford University Press, New York.

Conrad V., Pollak L.W. 1950. Methods in climatology, 2nd edition, Harvard University Press, Cambridge, Massachusetts.

Dalezios N.R. and Bartzokas A. 2009. Daily precipitation variability in semiarid agricultural regions in Macedonia, Greece, Hydrological Siences Journal, 569-585.

Eckstein B.A. 1989. Evaluation of spline and weighted average interpolation algorithms, Comput Geosci, 15, 79-94.

Gorczynski L. 1918. On a method of calculating the degree of continentality depending on the temperature, Comptes Rendus, Societé des Sciences et des Lettres de Varsovie, fasc. 4, 11, 500.

Gorczynski L. 1922. The calculation of the degree of continentality, Monthly Weather Review, Vol. 50, 370.

Hutchinson M.F. and Gessler P.E. 1994. Splines-more than just a smooth interpolator, Geoderma, Vol. 62, 45-67.

Jensen M.E., Burman R.D. and Allen R.G. 1990. Evapotranspiration and irrigation water requirements, ASCE Manuals and Reports on Engineering practice, New York, No. 70, 332.

Kanli L. 2009. Comparison of river typology systems in Greece, Interdepartmental Postgraduate Program "Ecological Water Quality and Management at a River Basin level, Master Thesis, A.U.TH.

Kerkidis P., Michalopoulou H., Papaioannou G. and Pollatou R. 1996. Water balance estimates over Greece, Agricultural Water Management, 32, 85-104.

Mardikis M.G., Kalivas D.P. and Kollias V.J. 2005. Comparison of Interpolation Methods for the Prediction of Reference Ecapotranspiration - An Application in Greece, Water Resources Management, 19, 251-278.

Matheron G. 1970. The theory of regionalized variables and its applications, École Nationale Supérieure des Mine, Les Cahiers du Centre de Morphologie Mathématique de Fontainebleau, Paris, Vol. 5, 212.

Mikolaskova K. 2009. A Regression Evaluation of Thermal Continentality, Geografie, Proceedings of Czech Geographical Society, Vol. 4, p. 114.

Nastos P, Evelpidou N. and Vasilopoulos A. 1999. Spatial distribution of Annual Temperature range at Greece using GIS, $1^{\text {st }}$ Conference on Geographic Information Systems, Greek Society of Geographic Information Systems.

Palmer W.C. and Havens A.V. 1958. A graphical technique for determining evapotranspiration by the Thornthwaite method, U.S. Weather Bureau.

Pereira A.R. and Camargo A.P. 1989. An analysis of the criticism of Thornthwaite's equation for estimating potential evapotranspiration, Agricultural \& Forest Meteorology, 46, 149-157.

Penman H.C. 1948. Natural evapotranspiration from open water, bare soil and grass, Proc. R. Soc. Lond., Vol A193, 120-145.

Sailesh S., Dilip K. P., Debasish L. and Babita P. 2012. Interpolation of climate variables and temperature modeling, Theoritical Applied Climatology, 107, 35-45.

Supan A. 1880. The distribution of the year union Warm variation on the earth's surface, Z. For knowledge, Geographie, Vol. 1.

Thornthwaite C.W. 1948. An approach towards a rational classification of climate, Geographical Review, 38, 55.

Tobler W. 1970. A computer movie simulating urban growth in the Detroit region, Economic Geography, 46(2), 234-240.

Watson D.F. and Philip G.M. 1985. A refinement of inverse distance weighted interpolation, GeoProcessing, 2, 315-327.

WFD 2007. Intercalibration technical report. Mediterranean GIG - Rivers Benthic Invertebrates.

Zampakas I. 1981. General Climatology, 176-177. 